\title{
John Calvin and the Belgic Confession
}

\author{
S.A. Strauss \\ Department of Dogmatology \\ University of the Orange Free State \\ BLOEMFONTEIN
}

\begin{abstract}
Calvin's influence on the Belgic Confession is usually taken for granted. In this article this traditional view is subjected to a critical study. Firstly a historical investigation is made of the possible biographic contact that John Calvin (1509-64) and Guido de Brès (1522-67) could have had. This investigation leads to the conclusion that the latter was a close pupil of the former. (alvin exercised influence on the Belgic Confession (1561) via the Confessio Gallicana (1559). When comparing the general theological content of the Belgic Confession with the Institutes of Calvin, significant similarities are found.

Finally some doctrinal themes found in the Belgic Confession are discussed in more detail, after which they are compared with Calvin's statements in the Institutes. The doctrines on the revelation and Scripture, as well as on the church and church government, are selected as examples. This subsection leads to the same conclusion: Calvin had a definite influence on the Belgic Confession. The Belgic Confession should therefore be read and interpreted in the light of Calvin's writings.
\end{abstract}

\section{Introductory remarks}

The present circumstances in which we find ourselves in our country are such that most people, like the Athenians of old, have no desire other than to say or hear something new (Acts 17:21)! It is in times such as these in particular that it is absolutely essential to listen to the past - without neglecting the present or the future. The existence of the Christian church as such, - in its unity, holiness and catholicity - is after all directly dependent on its apostolicity, that is its devotion to the faith that was once entrusted to the saints (Jude 3).

The motivation for writing this article was to make a contribution to the existing body of knowledge concerning the conviction that the church can only be true to its intended nature when functioning in accordance with Scriptural truth. As the confession of De Brès and the work of Calvin are illustrative examples of this 
conviction, their lines of thought are utilized in this article: an approach which can be beneficial to both the church and the furthering of theology in our country.

As far as I know Calvin's influence on the Belgic Confession has not been studied explicitly before - the influence is usually taken for granted. Even a brief exploration of the field, however, is sufficient to convince one of the possibilities that an intensive study could have. Obviously problems do exist. The first is the scope of the theme: Where should one begin, and where should one end? Another problem is the availability of the original (European) sources. What is submitted here, is presented with the expectation that it will contribute to South African research on Calvin.

In my opinion the best method for gaining an insight into the nature of Calvin's influence on the Belgic Confession is to explore the historical link between the two. The history of the origin of the Belgic Confession, as well as the biographical contact between its author, Guido de Brès ${ }^{l}$, and Calvin has therefore to be studied. Subsequently the relationship in theological content in the work of Calvin and the Belgic Confession will be discussed. Apart from a general comparison, a number of selected themes will be discussed more fully. The paper ends with a general conclusion.

\section{Historical line}

\subsection{History of the origin}

The history of the origin of the Belgic Confession can be reconstructed with a considerable degree of certainty. One of the most reliable and detailed renditions is that of Bakhuizen van den Brink (1976) which mentions the best historical sources.

Early on the moming of 2 November 1561 a sealed parcel was found in the walls of the castle at Tournay, situated in the present-day Belgium. The parcel contained a letter on behalf of the citizens, addressed to the city authorities, as well as a printed booklet entitled Confession de foy (Confession of faith). The reason for this public defence of their viewpoint was the persecution to which the Reformation-oriented local population had been exposed for decades. Since as early as 1528 and thereafter, many of them had been tried and executed in Tournay for their religious convictions. These Protestants, who made no secret of being Calvinistic, already constituted half the population of Tournay by 1561 .

1 De Bres's sumame is sometimes written De Bray and his first name Guy. I have followed the spelling that scems to be used most frequently (Van Langeraad, 1884:9; Dankbaar, 1946: 10) 
From 1559 the dynamic preacher Guido de Brès served the French-speaking congregation in secret. Although their minister did not favour the idea, many of them participated in psalm processions (chanteries) in the streets during the autumn of 1561. The Confession de foy which De Brès wrote, had been distributed in the streets on 29 September 1561. When the Spanish land owner, Margaretha, gave instructions to suppress the 'chanteries' by force, the houses of suspected leaders were searched. On 15 October a copy of the Confession as well as a letter to the authorities - a duplicate of the one thrown over the wall two weeks later - was found. De Brès had probably written the letters, but the authorities did not know it at the time. By the time they started looking for him, he had already fled the city. From their subsequent report it was clear that they only found his secret quarters on 10 January 1562. In it were 200 copies of his Confession de foy, as well as numerous other books, among others, books by Luther, Zwingli, Bucer, Bullinger and Calvin . 2

\subsection{Guido de Brès}

There is little doubt that Guido de Brès drew up the Confession, although he could have done it in conjunction with his colleagues (Van Langeraad, 1884:116, Dankbaar, 1946:16; Van der Linde, 1976:83). In order to establish the relationship between his Confession and Calvin, it is therefore necessary to determine whether he had any personal contact with Calvin.

De Brès had an eventful life. He was born in Mons in 1522 and was educated as a Catholic. Although his home language was French, he would certainly also have known the Dutch (Flemish) language in the area where he grew up (Vonk, 1955:13,21). Later, in 1566, he even translated a Dutch book into French (Van Langeraad, 1884:60). In 1547, before he was 25 years old, he broke with the Roman Catholic church and accepted the doctrine of the Reformation. Like many of his contemporaries and compatriots he had to flee to England that same year. In the French-speaking section of the Dutch refugee congregation in London he received his first theological training from competent Reformed theologians like a Lasco and Datheen (Exalto, 1987:13). In London he certainly became acquainted with the views of Calvin (cf. Rutgers, 1980:24,178-180). After his return to his fatherland in 1552, he became a travelling preacher. In 1555 his first book Le baston de la foy (hrestienne (The supporting stick of the Christian faith) was

2 Cf for details the onginal letter from the commissioners to Margaretha - the letter which was copied by Van Langeraad (1884.45 ct seq). Van Itterzon (1981:98) mentions the following deseription of De Bres given bs an arrested person. 'He is a man of about 40 . tall. palc, rather thin with a long face and reddish beard ... he looks dishevelled in his black coat ...!' 
published. In this book he effectively defended the dogma of the Reformation against the Roman Catholic dogma. Vonk (1955:35-64) gives a brief overview of this work. This overview mainly consists of a summary of the statements of wellknown church fathers - a summary which proves the extent of the author's reading.

In 1556 De Brès had to flee again, this time to Frankfurt. He could have met Calvin personally then, as Calvin visited the Dutch refugee congregation there for three weeks at that time (Van Langeraad, 1884:21; Van Itterzon, 1981:98). Before returning to his country of birth in 1559 , he continued his studies in Lausanne and Geneva with Beza and Calvin (Doekes, 1979:43). Dankbaar (1946:12) states that he attended sermons, lectures on the Bible and public lessons by Calvin. It is known that he had a high opinion of Calvin as theological teacher, and that he probably exchanged letters with him as early as 1556 (Van Langeraad, 1884:22; Rutgers 1980:16,140). The basis for this assumption is a letter from Calvin to De Brès.

It is maintained that already in 1559 , shortly after his return to the Netherlands, De Brès started collecting a number of creeds on which the supporters of the Reformation agreed. An acquaintance of his, Saravia, is said to have shown a draft creed to Calvin in Geneva in 1559. Calvin's advice to De Brès was rather to accept the Confessio Gallicana (1559) than to draw up a separate creed for the Netherlands (Vonk, 1955:107). Presumably Calvin was afraid that new creeds would bring new division in the Reformed church (Van der Linde, 1976:80). Initially De Brès obeyed his teacher's wishes, but two years later he considered the time as ripe to publish his own confession. The reason for this can probably be found in the unique circumstances in the Netherlands where the French were not too popular at the time (Vonk, 1955:108). ${ }^{3}$

As far as the rest of De Brès's life is concerned, the following is germane to this study. In the first few years after he had fled Tournay he was minister in the French city Sedan. During this time (in 1564) he was in contact with, among others, William of Orange in Brussels, regarding the reunion of Calvinists and Lutherans (Van Langeraad, 1884:61,62,123; Dankbaar, 1946:27; Vonk, 1955: 20). In 1565 another important book of De Bres was published: La racine, source et fondement des Anabaptistes (The roots, origin and foundations of the Anabaptists). It is interesting that he refutes the Anabaptists' views on incarnation, infant baptism and the authorities by name - all aspects that had already been addressed in his Confession of 1561. As one of his sources he mentions Calvin in the foreword of his book - alongside a Lasco, Bullinger and Micron

3 Van Langeraad (1884:150), however, questions the historical correctness of these contentions 
(Augustijn, 1983:182). In 1566 De Brès was back in his fatherland, first in Antwerp and later in Valenciennes. After an iconoclasm this city closed its gates to the authorities, but in March 1567 it was taken after a siege. Margaretha was out for the blood of the clergymen, and on 16 April De Brès was arrested. From his death cell he wrote touching and pious letters, among others to his mother and wife. On 31 May 1567 he, as well as his colleague Peregrin de la Grange, died on the gallows as martyrs for their faith.

\subsection{History of the text}

An overview of the history of the text of the Belgic Confession can also assist us in determining its relationship with Calvin. Historically the following line links Calvin and De Bres's Confession (1561): the latter being dependent on the French Confession (1559), which in turn was founded on a draft of Calvin (Neuser, 1980:296). The chairman of the Synod of Paris (1559) had asked Calvin's advice on drawing up a communal creed and in spite of his opposition to the plan, Calvin sent a number of representatives with a 35 article draft to the Synod. This document was based on the 18 articles of the Paris Creed (1557). Only a few changes were made to Calvin's draft by the Synod of 1559 , in particular changes regarding the creed as Word of God (Doekes, 1979:50-51). The exact text of the French Confession, with the amendments to Calvin's original proposal, can easily be compared to the Confession of De Brès, as described and copied by Bakhuizen van den Brink (1976:53-57, 70-146). In general the two correspond to a great extent.

Several editions of the French text of De Brès's Confession de Foy were published. As early as 1562 it was translated into Dutch and the translation was also reprinted several times. Eventually the Synod of Dordrecht, at its 173rd session, accepted and signed both the amended and approved French and Dutch texts on 24 May 1619. These two texts have since served as the authentic text of the Belgic Confession. Bakhuizen van den Brink (1976:11-27) gives a full description of this development. A critical study of the text of the Belgic Confession does not produce essential differences between the texts of 1561 and 1619 .

\section{General comparison}

\subsection{Calvinistic stamp}

In general it can be stated that the Belgic Confession bears an unmistakable Protestant stamp. This feature is already apparent in the Belgic Confession's clear anti-Roman Catholic bent. Compare, for example, the articles on the sufficiency of the Bible (7), the radicalness of the fall (14), the justification through 
faith alone (22), the marks of the true and the false church (29), and the sacraments (33).

However, the Belgic Confession is not only overall Protestant, but is particularly Calvinist in nature. That is probably why De Brès openly chooses Calvin's viewpoint rather than that of Luther in the article on, for example, the two natures of Christ (19) and the article on holy communion (35). Like Calvin, and even more strongly than in his draft creed (1559), De Brès specifically names the heresies of the Anabaptists. In this regard also compare the articles on the incarnation of Christ (18), on baptism (34), and on civil authorities (36). By way of a comparison like this the unique nature of the Belgic Confession can clearly be seen. The specific nature of the Belgic Confession should, however, be explained against the background of De Bres's personal experiences with the Anabaptists (Doekes, 1979:55). In the Belgic Confession De Brès continued consistently in the direction already indicated by his teacher, Calvin (cf. Balke, 1977 for Calvin's struggle against the Anabaptists). Parallel to his dependence on Calvin, De Brès therefore also shows his independence of Calvin. Vonk $(1955 ; 1956)$ in particular, compared the Belgic Confession in detail with De Brès's other writings on the Anabaptists.

\subsection{The Belgic Confession compared to the Confessio Gallicana}

A comparison of the Belgic Confession and the Confessio Gallicana which, as we have seen, mainly originated from the hand of Calvin, can also cast light on our subject of study. Exalto (1987:26-35) pointed out the following similarities. In article 1 of the Belgic Confession the confession about God is almost word for word the same as the first article of the Confessio Gallicana. Article 2 of the Belgic Confession regarding the dual revelation of God is taken over completely from the Confessio Gallicana. In the articles on Scripture (3-7), the Reformed biblical principles are confessed as strongly as in the Confessio Gallicana, differing only in that the Belgic Confession has a complete article (6) on the apocryphal books. Occasionally the Belgic Confession is more detailed than the Confessio Gallicana, for example in the articles on predestination (16), baptism (33), and the authorities (36) - but there is no essential difference. An interesting point is that the last article in the Belgic Confession on the last judgement (37) is not found as a separate article in the Confessio (jallicana. Our forefathers considered these two confessions to be so similar that the Dutch Synod of Emden (1571) endorsed and signed both (Doekes, 1979:52). This was the ecclesiastical confirmation of the Calvinistic content of the Belgic Confession. 


\subsection{The Belgic Confession compared to the Institutes}

Several researchers have made extensive reference to the relationship between the Belgic Confession and the literary inheritance left by Calvin, namely his Institutes. Koopmans (1983:14) probably served as an inspiration for Polman (s.a.(a):5), whose objective was a commentary on the Belgic Confession in the spirit of Calvin.

In general it is significant that the Belgic Confession, like the Confessio Gallica$n a$, uses the same classification principle as Calvin in the final edition of his Institutes (1559). This is the well-known trinitarian classification of the first three books (knowledge of God the Creator, the Redeemer and the Sanctifier), with the fourth book on the 'external means by which God brings us to and preserves us in communion with Christ'. This is basically the same order as the Apostolicum (Koopmans, 1983:99). De Brès is also truly Calvinistic in outlook in not taking the Reformational dogna as a new dogma, but in stating that he only wanted to confess anew the catholic dogma of the earlier ecumenic councils. Like Calvin, De Brès is not ashamed of his commitment to the orthodox churcl fathers (cf. for example article 8 on the Trinity and article 19 on the two natures of Christ). Nevertheless, some differences do exist between the Institutes and the Belgic Confession. Calvin deals extensively and expressly with the covenant (Inst. 2.1011), and Christ's tripartite office (Inst. 2.15), while the Belgic Confession only mentions the former briefly (in connection with infant baptism, article 34), and the latter not at all. Another difference is the positioning of the part on the predestination: in the Institutes (3:21-24) this part is placed following upon the articles concerning justification and prayer and preceding the article concerning the last resurrection, while the Belgic Confession inserts this part between the articles on sin and redemption. One should not conclude, however, that the Belgic Confession is not Calvinistic in nature. On the contrary, the Confessio Gallicana (by Calvin's own hand) in this respect follows exactly the same classification as the Belgic Confession!

At least one more obvious similarity between the Institutes and the Beigic Confession can be pointed out: both are preceded by a letter to a king - the former to Francis I and the latter to Phillip II. Both letters contain very similar apologies for the cause of the Reformation addressed to the authorities.

After this general comparison it is necessary to compare in more detail some theological themes from the Belgic Confession with Calvin's way of thinking, particularly as Calvin's lines of thought are to be found in the final edition of the Institutes. The detail with which the Belgic Confession deals with certain themes, served as a criterion for the selection of a number of topics. 
Only two doctrines will be discussed in this article: revelation and Scripture, and church and church government. It is not the intention to reproduce in detail what the Belgic Confession or Calvin said about these subjects, but rather to concentrate on the essence in order to establish the relationship between the two doctrines.

\section{Revelation and Scripture}

\subsection{Dual revelation}

The Belgic Confession offers a detailed confession in respect of the revelation of God, as we receive it by Holy Scripture (articles 2-7). What is confessed here refers back to the Confessio Gallicana, which expresses the same truth in articles 2-5, but in a more concentrated form. Calvin's original draft for the Paris Synod had only one article instead of articles 1-5 of the Confessio Gallicana (Bakhuizen van den Brink, 1976:70-78). In this article Calvin wrote succintly that the living God revealed himself in his law, the prophets and eventually the gospel, as witness to salvation. That is why we accept Holy Scripture as the only infallible truth. On authority of these words Neuser (1980:296 et seq.) concludes that Calvin deduced the authority of Scripture from its contents. Neuser regards the expansion of the Confessio Gallicana as a theological shift. According to Neuser this shift is indicated by the positioning of the more general article on the (dual) relevation of God. This more general article namely precedes the dogma regarding the importance of Scripture. While Calvin's argument takes God's will of salvation as point of departure and then proceeds to the necessity of Scripture, the Confessio Gallicana (and also the Belgic Confession) first determines the divine authority of Scripture on the basis of the inner testimony of the Spirit. Whether this development was really un-Calvinistic still remains to be seen.

It cannot be denied that express mention of a dual revelation and knowledge of God in the Belgic Confession and the Confessio Gallicana (article 2) has solid foundations in Calvin's own writings. In the first chapters of the Institutes 1 he firstly deals with aspects concerning the knowledge of God which is revealed by the creation of and God's reign over the world (cf. 1.5), before he discusses the necessity of Scripture (1.6). Article 2 of the Belgic Confession follows this pattern closely. Inevitably this duplex ordo could be misunderstood, as should a scholastic dichotomy of natural and supernatural knowledge of the existence of God was being taught. But this is obviously not the intention of either Calvin or De Brès. The subject of the sentence starting with "we know" is indeed the Christian congregation. In addition, the confession is made on account of Romans 1:20 that the revelation in creation and providence is sufficient to convince people of God, and at the same time deny them the possibility not to believe in 
God's existence. The comparative element in the second part of article 2 should therefore be noted: even more clearly and more completely (than in the creation) God reveals himself to us through his Word. In this regard the well-known image Calvin uses is illuminating: Scripture supplies the "glasses" helping us to see more clearly the knowledge of God that lies unorderedly in our minds (Inst. 1.6.1, cf 1.14.1). Consequently the criticism of K. Barth (cf. Polman, s.a.(a): 159-175) and many of his followers which is levelled at article 2 cannot be sustained. This assumption does not, however, deny that subsequent Reformed orthodoxy sometimes misused article 2. However, the faithful confession of the selfrevelation of God, also in creation and providence, remains one of the comer-stones of the Calvinistic belief regarding the relationship between creation and recreation, nature and grace respectively - a relationship that was continuously slanted by Rome as well as the Anabaptists (cf. Van't Spijker, 1986, especially: 42,68, 72).

\subsection{Elements in detail}

The significantly detailed confession of the Belgic Confession on Holy Scripture consists of the following elements: the Belgic Confession starts with a confession of the divine origin of Scripture (article 3). God, with his exceptional care for our salvation, in order to preserve his Word, commanded his servants to translate his revealed Word into writing. Following upon this, the 66 canonical books of the Old and the New Testament against which nothing can be alleged are named (article 4). Furthermore the authority of Scripture - as rule, foundation and confirmation of our faith - is confessed next (article 5). We accept the authority of Scripture because the Holy Spirit testifies in our hearts that the authority of Scripture is vested in God, although the Holy Spirit also has the evidence in itself. The next article (6) distinguishes clearly between the 'holy' and the apocryphal books, which are named. The church may read the latter and gain learning from them, but only as far as they agree with the canonical books. Finally the Belgic Confession confesses the sufficiency of the Bible (article 7). The Bible contains the expression of God's will - guidelines serving both faitli and religion (dogma and life). No one may therefore teach anything else, and no other writings may be equated with Holy Scripture. The truth of God reigns supremely. Everything that does not agree with this infallible rule is therefore rejected.

Also in this respect the Belgic Confession agrees with Calvin, as any expert on the Institutes would see. In 1.7 Calvin deals with Scripture in almost the same order as the Belgic Confession. Compare for instance McKim (1984:50-58) who consecutively discusses Calvin's view on the necessity, the nature and the authority of Scripture. Firstly he states that the living Word of God Himself can be heard in Scripture (1.7.1). Scripture has its origin in God; it comes to us through the mediation of men from the mouth of God Himself (hominum ministerio, ab ipsissimo Dei ore 17.5). Calvin also proves that Scripture cannot 
derive its authority from the church (1.7.2), but that the 'hidden' or 'inner testimony of the Spirit' convinces us of its divineness (1.7.4). In addition, Scripture is reliable in itself (1.7.5 where Calvin uses the Greek autopiston, C.R. XXX:60).

Reasonable evidence could therefore be put forward to confirm the reliability of Scripture (cf. the complete 1.8). What the Belgic Confession confesses on the sufficiency and perfection of Scripture, would have been fully approved by Calvin. In contrast to the co-ordination of Scripture and tradition by the Council of Trent (1546), it was even at that time very topical for all Reformers to maintain the well-known sola scriptura. Polman (s.a.(a):248-265) discusses this question and concludes by quoting the well-known words of Calvin: "The Word of God is the highest judge in all disputes."

\subsection{Conciseness: advantageous and detrimental}

Naturally De Brès does not formulate his Confession in such detail as Calvin does in his Institutes. This fact can have advantageous or detrimental consequences. The advantage of the conciseness of the Belgic Confession can be illustrated on the basis of the theological question of inspiration. Calvin's view of inspiration has occupied researchers of his work during the past years. Whether he advocated a verbal inspiration of the Bible, or what it exactly means, remains unanswered (cf. McKim, 1984:58-64). Fortunately the Belgic Confession does not present a theological inspiration theory! In accordance with the unique nature of an ecclesiastical confession it simply confesses the faith of Christians of all ages that the Bible is the Word of God - even without quoting 2 Timothy $3: 16$ ! From this confessional point of departure it remains the calling of theologians to develop this inspirational faith into an inspirational doctrine.

As mentioned earlier, the strongly concentrated nature of confessions can also be a negative aspect. The brief reference to the Holy Spirit (article 5) in the Belgic Confession can, for example, give rise to various spiritualistic and speculative thoughts. Because the Belgic Confession and the Institutes agree in principle to such a great extent, such an expression should be explained in the light of what Calvin himself said on the subject. In Book 1 he devoted a separate chapter to the fanatics who advocate a division between Scripture and the Spirit. Calvin stated that God joined the certainty of his Word and his Spirit with mutual ties (1.9.3, mutuo nexu Dominum verbi spiritusque inter se copulavit, CR XXX:71). Later (4.8.13) he returned to the authority of Scripture. Contrary to the Roman Catholic conception that the Spirit could manage the church without the Word, Calvin maintained that the Spirit works by means of the Word; the Spirit wants to be joined to God's Word with unbreakable ties. What the Belgic Confession means by the testimonium Spiritus Sancti internum, cannot be any different from what Calvin understood it to be. It is therefore not a prompting of the Spirit out- 
side the revelation of the Word, but a testimony of the Spirit with and through the Word which convinces us that Scripture comes from God (Bos, 1977:32; cf. Schilder, s.a.21 et seq. for criticism on V. Hepp in this respect).

\section{Church and church government}

\subsection{The importance of the church}

Calvin devoted a very large part of his Institutes - one third (Walker, 1984:218) to the church. In the Belgic Confession no fewer than six of the 37 articles are devoted to the church. This demonstrates the importantce of this theme in the Reformers' reflections on the Christian faith.

In the Confessio Gallicana, nine of the 40 articles deal with the confession regarding the church. More or less the same facets as in the Belgic Confession are dealt with, but in a different order. Where the Confessio Gallicana (article 25) starts with the clergymen (pasteurs) who are used by God to govern his church, the Belgic Confession (article 27) begins more logically with a definition of the church. In this respect the Belgic Confession follows the Institutes even more closely than the Confessio Gallicana (Vonk s.a.(b): 105). When he discusses the church as the first external aid in Institutes 4, Calvin also directly begins with a definition of the church as our mother from whom we may not withdraw ourselves (4.1, cf. Belgic Confession articles 27 and 28). Only after that does he discuss the true and false church (4.2, cf. Belgic Confession article 29), and the offices and government of the church (4.3, cf. Belgic Confession article 30-32). Battles (1980:281-351) gives a useful survey of this aspect.

The fact that the Belgic Confession, contrary to the Confessio Gallicana and the Institutes, positions the article concening the church before the article on the last judgement, may create the impression that De Brès regarded the church as a complete part of the salvation in which we believe. It is then maintained that in the Institutes (only in the fourth book!) the church is given a more or less secondary place (Graafland, 1989:11-14). In my opinion, however, this is not a strong argument aiming to prove a difference between the Belgic Confession and Calvin. Calvin did not regard the fourth book of the Institutes as a kind of appendix. The four parts of this work can be divided into three sections: creation (1), the fall (2.1-2.5), and salvation (2.6 to the end of 4) (Milner, 1970:193). Against this background the church, in each case, also in the Institutes, forms part of the Christian faith. 


\subsection{Significant expressions}

Exactly how closely De Brès followed Calvin can be illustrated by studying some of the significant expressions in his confession. When the Belgic Confession states that the one, holy, catholic church will exist for ever, reference is made to the biblical evidence that even in the dangerous time under Ahab seven thousand people did not bend the knee before Baal. Calvin used exactly the same argument in his letter to King Francis I! Directly after that he wrote a sentence that was used almost verbatim by De Brès in article 27: 'There should be no doubt in us that Christ, since the time of his ascension, has always ruled on earth' (semper in terris regnaverit Christus ex quo coelum ascendit, C.R. XXX:23). De Brès said: Christ is an eteral King who can never be without subjects. The catholicity of the church is therefore not an inherent, static quality of the church, but something that is guaranteed by Christ, the Head of the church. This is the inherent meaning of the expression "we believe in a holy catholic church" (Heid. Cat. 21).

In article 28 of the Belgic Confession De Brès takes on the (controversial) statement of St Cyprian: "As this holy meeting is a gathering of those who are redeemed. we believe that outside it there is no salvation' (Latin extra eam nulla salus). This expression is also taken from the Institutes 4.1.4. The correct interpretation of this statement has been widely discussed. Graafland (1989:41-43) points out that Calvin uses this expression (which sounds Roman Catholic) in reaction against the Anabaptists' disrespect for the church. However, Calvin gives this expression a Reformed content: because the church is where the Word is, and because we can only be reborn through the Word, we can only share in salvation within the church. Other writers, such as Polman (s.a.(b):291), when discussing the Institutes ' views on the church, work with the (equally controversial) distinction between visible and invisible church, and then eventually conclude that both Calvin and De Brès (primarily) meant the invisible church when they used this expression!

It cannot be denied that by his somewhat ambiguous use of language, Calvin himself gave cause for this dodging between 'visible' and 'invisible'. In this respect his line of thought also developed, as he gradually asked more and more attention for the visible church (Graafland, 1989:12). We must accept that the Belgic Confession in article 28 , as in articles 27 and 29 , refers to the one, holy, catholic church and not to one particular church institution or denomination. It is outside this church - the holy assembly of all who truly believe in Christ, who all expect their full salvation in Jesus Christ - that there is no salvation (Schilder, s.a.:92).

The extent to which Calvin esteemed the church can also be seen in his exceptionally sharp censure of those who separate themselves from the church - a thought 
which is also expressed in article 28 of the Belgic Confession: 'To leave the church is a criminal separation, a betrayal of God and Christ' (Inst. 4.1.10, discessionem ab ecclesia, Dei et (hristi abnegationem esse, CR XXX:755). 'He who leaves the external communion of the church, where God's Word is preached and the sacraments served, do not have a single excuse' $(4.1 .19$, nihil excusationis eum habere, CR XXX:762). De Brès goes further than the Confessio Gallicana (article 26) in this respect when he, apart from the negative prohibition on separating from the church, also includes the positive commandment that according to the Word of God it is the duty (1619 Dutch text: "ampt") of all believers to separate themselves from all those who do not belong to the church. This statement in the Belgic Confession is often interpreted as a call to break away from the Roman Catholic Church. It should be kept in mind, however, that while the Confessio Gallicana (article 28) expressly rejects the papal meetings (les assemblees de la Papaute), the Belgic Confession does not mention the Roman Catholic Church by name at all. Nevertheless, as a result of this interpretation the Dutch churches of the 19th century separation tradition (Afscheiding) also regarded article 28 as a call on them to break away from the national church which had become false (Polman, s.a.(d):167-171). Whether this deduction is justified is to be doubted. Exalto (1987:92-94) raises a strong argument that thuse who do not belong to the church cou!d s!so mean the unbelievers (e.g. "Jews and Turks") who are outside the church

Article 29 of the Belgic Confession deals with the distinction between the true and the false church and the characteristics of both. Contrary to the Confessio Gallicana (article 27), which describes the true church in general terms only as the communion of the faithful who follow the Word of God and the pure religion, De Brès expressly sums up three distinctive characteristics or marks (notae): the pure preaching of the Gospel, the pure administration of the sacraments and the excercising of church discipline. It is known that Calvin (Inst. 4.1.12) mentions only the first two characteristics. Does this mean that De Brès deviated from Calvin? Certainly not. Calvin mentions church discipline already in 4.1 .15 , and then discusses it at lenght in 4.12. In addition he discusses the ministers' instructions regarding the doctrine, the sacraments and discipline in 4.3.6. This is an example of De Brès's independence where he follows Calvin in spirit but not necessarily to the letter (Vonk, 1956:133).

\subsection{Church government}

As far as the articles in the Belgic Confession on church government are concermed (30-32), a large degree of similarity with Calvin can be indicated. I shall confine myself to the main issue. Article 30 starts with the premise that the church should be governed according to the spiritual form of government (police spirituelle), as taught in the Word of God. Although Calvin does not use exactly 
the same words, he begins his exposition of the servants of the church directly with the words "the order through which God wants his church to be governed" (Inst. 4.3.1). By spiritual form of government De Bres probably means a synopsis of the basic principle of the Reformed church government, namely that Christ is the only Head of his church (cf. articles 29 and 31). Under Him, says Calvin (Inst. 4.6.9) we are united in terms of the government which He Himself prescribed (ordinem et politiae formam quam ipse praescripsit, CR XXX:818).

According to this form of government, article 30 continues, there should be ministers or pastors, as well as elders and deacons, who together form the church council. Article 29 of the Confessio Gallicana mentions the same three offices. It is known that Calvin distinguished a fourth office, the teachers (doctores). This gradually became a school office in practice, and was therefore not considered with the other church offices, not in the French Church Order (1559) either (Polman s.a.(c):17-19). The Confessio Gallicana also mentions only three offices. The idea of a church council for each local church was also adopted directly from Calvin (Inst. 4.3.8, 4.11.6).

As far as article 31 of the Belgic Confession is concerned, the idea of the lawful election of the offices bv the church and the calling bv God is alsn a dnnted from Calvin. He discusses this matter at length in Institutes 4.3.10-16. An interesting point is that De Brès expressly adds that everyone 'ought to esteen' the ministers of God's Word and the elders of the church - the deacons, however are not mentioned here! Polman, (s.a. (c):45) remarks that this thought is not mentioned in the Confessio Gallicana, and that De Brès probably considered it necessary because of the negative experiences with the Anabaptists he had in this respect.

In article 32 De Bres expresses the conviction that although it is necessary and good to introduce a certain form of order to maintain the body of the church, we should take care not to deviate from that which Clurist, our only Master, instructed us. All human conceptions and all laws that bind and compel peoples' consciences should be rejected. Calvin discusses the same matter at length in the Institutes 4.10 . He strongly criticises the Roman Catholic institutions that bind consciences. He says, among others, (4.10.30) that he only approves of those human institutions that are based on God's authority, are taken from Scripture and are therefore completely divine (quae et Dei autoritate fundatae et ex Scriptura desumptae adeoque prorsus divinae sint, $\mathrm{CR}$ XXX:889).

\section{Conclusion}

The detailed study undertaken in the last two paragraphs could also be continued in respect of the other articles in the Belgic Confession. One only has to think of the obvious similarity between Calvin's views and what De Brès confesses on, 
for example, providence (article 13), election (article 16), justification (articles 22-23), sanctification (article 24), the relationship between Old and New Testament (article 25), the sacraments (articles 33-35), and civil authorities (article 36). If a postgraduate student at one of our theological faculties could undertake such a study, our knowledge of the Belgic Confession as well as of Calvin's theology would be enriched. It is to be hoped that the two examples I selected will illustrate sufficiently to what extent the Belgic Confession carries a truly Calvinian stamp.

Without becoming unnecessarily repetitive, one can conclude, on the basis of the historic line between Calvin and De Brès, that sufficient evidence exists that the latter was a close pupil of the former. On more than one occasion they were in personal contact with each other, and the pupil never contradicted his teacher openly. It is therefore a valid hypothesis that De Brès's Confession is closely related to Calvin's Institutes.

The history of the origin of the Belgic Confession and the history of its text also reveal a relationship to Calvin, especially via the Confessio Gallicana. To my mind Calvin did not respond anywhere to the Belgic Confession. Perhaps one could conclude from this silence that he had no objection to it, although he initially advised against its publication.

Our structural analysis of the Belgic Confession, in comparison to the Confessio Gallicana and the Institutes, supports the historical hypothesis. Although there are interesting variations between these writings, no evidence exists of any fundamental theological differences. In some respects the Belgic Confession even corresponds more closely to the Instimtes than the Confessin Fallicana does.

The study of the contents of two themes in the Belgic Confession and the Institutes (revelation and Scripture, as well as church and church government) confirms the formal similarity. In some respects an independent development of the material can be discemed in De Brès, but it remains an independence in association with Calvin. It would have taken too much time to undertake a detailed comparison of all the articles of the Belgic Confession and those of the Institutes. Based upon this evidence, one could expect that the result will be the same throughout.

Our final conclusion is that Calvin undoubtedly had an enormous influence on the Belgic Confession. In order to understand and explain this church symbol it is therefore essential to study it against the background of Calvin's writings. 


\section{Bibliography}

AUGUSTIJN C 1983. Brès, Guido de. (In Nauta, D et al. (red.) 1983. Biografisch lexicon voor de geschiedenis van het Nederlandse Protestantisme. Deel 2. Kampen: Kok. (p. 181-183.)

BAKHUIZEN VAN DEN BRINK, JN. 1976. De Nederlandse belijdenisgeschriften. Tweede druk. Amsterdam : Bolland

BALKE, W. 1977. Calvijn en de doperse radikalen. Tweede druk. Amsterdam : Bolland

BATTLES, F.L. 1980. Analysis of the Institutes of the Christian Religion of John Calvin Grand Rapids : Baker.

BAUM, W., CUNITZ, E. \& REUSS, E. ed. 1863. Corpus Reformatorum. Volumen XXIX etc Ioannis Calvini Institutio Religionis Christianae Brunsvigae : Schwetske.

hyk

$\mathrm{CR}=$ Corpus Reformatorum

BOS, C.G 1977. Geloven en belijden. Deel 1. Groningen : De Vuurbaak.

DANKBAAR, W.F. 1946. Hoogtepunten uit het Nederlandsche Calvinisme in de zestiende eeuw. Haarlem: Willink.

DOEKES, L. 1979. Credo. Handboek voor de Gereformeerde Symboliek. Tweede druk. Amsterdam : Bolland.

EXALTO, K. 1987. In het rechte spoor: inleiding tot de Nederlandse Geloofsbelijdenis Kampen : Kok.

GRAAFLAND, C. 1989 Kinderen van èen moeder: Calvijns visie op de kerk volgens zijn Institutie. Kampen : Kok

KOOPMANS, J 1983. Het oudkerkelijk dogma in de Reformatie, bepaaldelijk bij Calvijn. (Original edition 1938.) Amsterdam : Bolland

McKIM, D.K. ed. 1984. Readings in Calvin's Theology. Grand Rapids : Baker

McKIM, D.K. 1985. Calvin's View of Scripture. (In McKim, D.K. ed Readings in Calvin's Theology. Grand Rapids : Baker. p. 43-68.)

MILNER, B.C. 1970. Calvin's Doctrine of the Church Leiden : Brill.

NEUSER, W. 1980. Dogma und Bekenntnis in der Reformation: von Zwingli und Calvin bis zur Synode von Westminster. (In Andresen, C. (hrsgb). Handbuch der Dogmen - und Theologiegeschichte. Zweiter Band. Gottingen : Vandenhoeck en Ruprecht. p 167 352.)

POLMAN, A.D.R. s.a.(a). Onse Nederlandse Geloofsbelijdenis. Eerste deel. Franeker : Wever.

POLMAN, ADR. s a (b). Onze Nederlandse Geloofsbelijdenis. Derde deel. Franeker. Wever

POLMAN, ADR. s.a (c). Onze Nederlandse Geloofsbelijdenis Vierde deel. Franeker : Wever.

POLMAN, A.D. s.a(d). Woord en belijdenis eenvoudige verklaring van de Nederlandse Geloofsbelijdenis. Tweede deel. Franeker : Wever

RUTGERS, F.L. 1980. Calvijns invloed op de Reformatie in Nederland (heruitgegee deur W. van't Spijker). Leeuwarden : De Tille

SCHILDER, K. s.a. Christelijke religie: over de Nederlandse Geloofsbelijdenis. Kampen Copieerinrichting v d. Berg

VAN DER LINDE, S. 1976 Karakter en bedoeling van de Nederlandse Geloofsbelijdenis, belicht uit de geschiedenis van haar ontstaan ( $m$ Van der Linde, S. Opgang en voortgang der Reformatie. Amsterdam : Bolland p. 77-90.) 
VAN ITTERZON, B.P. 1981. Brès, Guido de (Guy De Bray). (In Krause, G. \& Müller G. (hrsgb). Theologische Realenzyklopadie. Band VII. Berlin : De Gruyter. p 97-100.)

VAN LANGERAAD, L.A 1884 Guido de Bray: zijn leven en werk. Zierikzee : Ochtman

VAN'T SPIJKER, W, 1986. Gereformeerden en Dopers: gesprek onderweg Kampen : Kok

VONK, C. 1955. De Nederlandse Geloofsbelijdenis (De Voorzeide Leer. Deel IIIa). Barendrecht: Barendrecht.

VONK, C. 1956. De Nederlandse Geloofsbelijdenis. (De Voorzeide Leer Deel IIIb). Barendrecht : Barendrecht.

WALKER, G.S.M. 1984. Calvin and the Church. (In McKim, D.K. ed. Readings in Calvin's Theology Grand Rapids : Baker. p 212-230.) 
